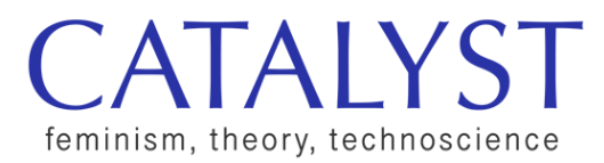

\title{
Book Review | Fables and Futures: Biotechnology, Disability, and the Stories We Tell Ourselves, by George Estreich (MIT Press, 2019)
}

\author{
Michelle Charette \\ York University \\ michgc@yorku.ca
}

Fables and Futures: Biotechnology, Disability, and The Stories we Tell Ourselves by George Estreich is a compelling reflection about the rise of biotechnological innovations, from non-invasive prenatal testing to CRISPR-Casg based genetic engineering. Estreich is a father of two daughters, one of whom is named Laura. At birth, Laura was diagnosed with trisomy 21 , or Down syndrome. Laura's condition can be linguistically classified in these two ways. Both are constitutive of different (sometimes harmful, sometimes productive) metaphors and ways of understanding what a diagnosis of this kind means. Estreich skillfully analyzes the discursive practices surrounding new biotechnology as if they were works of literature. He frames most of his critiques within the realm of language, and his story is about how certain technologies script the unscripted (p. xvii), shaping what is nebulous through persuasive tools not so unlike those used by literary masters.

Estreich's story is a many-years-in-the-making reflection on how disability narratives and genetic innovations, when coupled, can cause epistemic violence. Each chapter focuses on a single biotech application, both contemporary and historical, and he uses them as platforms to reflect on the narratives within which they are couched. This is ambitious, but Estreich is provident; he does not dwell 
on scientific innovation in great technical detail. Rather, he spends most of his time gesturing towards how proponents of biotechnological innovations, institutions, and devices traffic in the business of perpetuating harmful discursive practices related to what it means (or does not mean) to be genetically "disabled." Estreich selectively uses personal anecdotes to buttress reflection. The book is appropriate for a broad audience.

In the book's best moments, it is a poetic and informative account of how biology became and is still becoming a synonym for optimized bodies and optimized people. This is important: Estreich is writing in "a moment of provisionality" (p. $x v i i)$. Many of the innovations he discusses are still in nascent stages of development or on the margins of popularity and accessibility. The book reads as a journey through biotechnological progress. And indeed, the Introduction begins with a journey. The same year that Estreich finds out about Laura's diagnosis, he takes a road trip with his friend Robert. He writes that, in this moment, he was trying to answer the question that disability had posed. Estreich and Robert arrive in the Oregon desert, and in a moment of reflective and solitary cloud gazing, he writes, "one cloud stayed, pink as the inside of a grapefruit. It was different. The other clouds were, definably, volumes, objects in the sky. A child could look up and say Car or Horse. But this one had no shape you could name by likeness. It was a blur, a region of unfocus, a mist" (p. xii). This moment stands out as a signal for what to expect of the book. Estreich uses the rhetorical device of metaphor to both make sense of something nebulous and to linger on the unknown. The critiques he makes throughout the book are related to misused metaphorsmetaphors that "make sense" of difference by rejecting the unknown. One of the only certainties he seems willing to espouse is that people-changing technologies are more likely to be used wisely if more people talk about them (p. xvii).

Estreich discusses the utopic (and therefore dystopic) science-fiction-esque world of genetically engineering children. The book takes the Princeton biologist Lee Silver as its launch pad for reflecting on idealized narratives about children. Furthermore, he describes the ways in which Francis Galton's Essays in Eugenics took for granted that improved intellect is better (p. 13). One of the devices used to perpetuate this was the alphabet metaphor. Galton argued that citizens could be divided into classes "A through X" (p. 13). As a persuasive device, this metaphor is inspired, simple and linear. Estreich attributes much of the advent of genomic editing to the ideologies persuasively promoted by Galton. He then goes on to provide a very clear description of clustered regularly interspaced short palindromic repeats (CRISPR-Casg) gene editing, how it is used, and how it has 
been re-engineered for gene editing (cutting out undesirable DNA).

He writes that "CRISPR is sometimes described as a 'word processor,' able to 'cut' and 'paste' lengths of DNA at selected locations, a metaphor which subtly oversells CRISPR's accuracy" (p. 16). Indeed, it is still in very early stages of development. But this is not uncommon for biotechnologies, and the enthusiastic, "sketchy and too eager" (p. 17) venture capitalists who nevertheless sell images of perfection. What is sold, he writes, is a future adult who "has it all." "All" here means physical and mental superiority. But superiority does not equal health, and the euphemistic vagueness of the language suggests that "less-than-superior" is the equivalent to "possible genetic issues," which falsely pathologizes conditions that are treatable, or far from debilitating. He describes this binary as promise or peril, "two roads diverge, as it were, and all we have to do is take the right one. But gene editing is more like terraforming, changing the landscape, the idea of roads, the people who walk on the roads" (p.25). This binary makes it all the more difficult to see disability as lived, as actually experienced in time and place.

None of Estreich's criticisms are necessarily novel (see Clare, 2017; Ginsburg, 1989; Rapp \& Ginsburg, 2001; Schwartz, 2007). Disability studies is a robust contemporary arena of scholarship that tackles many of the themes found in Fables and Futures. For instance, activist and writer Eli Clare engages with similar ideas in his book titled Brilliant Imperfection. Indeed, it is possible that Clare does so with even more attention to nuance, writing that "we need neither a wholehearted acceptance nor an outright rejection of cure, but rather a broadbased grappling" (2017, p. 14). Clare too argues that eradication is at the center of the notion of cure, and that this kind of thinking commits a particular kind of violence.

But what Fables and Futures lacks in original insight it makes up for in method. The style of memoir opens up a space of intelligibility that is sometimes lacking in philosophical and STS scholarship. Memoir is a particularly lucid method for communicating the nuances involved in topics such as genetic testing. This is because, as Estreich rightly points out, family is the arena where the personal and the theoretical meet. It would be far from sufficient to discuss biotechnological innovations simply as technologies. Technological innovations do not exist in a vacuum. They have long legs, and memoir as method seems particularly capable of capitalizing on such complexities.

There is a growing body of literature that uses the method of memoir to make 
experience-based socio-political critiques. For instance, in Neurological Disturbances and Time Travel (2019), science and technology scholar and anthropologist Denielle Elliott uses the genre of ethnographic memoir to discuss the embodied effects of anomic aphasia, a condition that can arise post-brain trauma injury, whereby the individual might struggle to recall certain words, names, and memories. Insofar as it remains true that neurologists struggle to offer reductive explanatory accounts of aphasia, for instance, Elliott poignantly writes that "the lived embodied, felt accounts of brain injury and memory disturbances can bridge the gaps between the social and scientific in understanding brain trauma and forgetfulness" (2019, p. 17). The salient takeaway of this piece is that the genre of memoir opens up an often closed-off space for understanding medical conditions as new states of being. Insofar as normative methodologies continue to stifle or render obsolete the first-person accounts of those who actually live with so-called atypical medical conditions, those writing in the field would be prudent to see alternative genres like memoir as useful for "their generative possibilities and productivities" (Elliott, 2019, pp. 17-18).

Fables and Futures is a prod at innovations targeting the significance of genomic difference. What does "genomic distinction/difference" mean? Are notions of difference inextricably linked to social, political, and epistemic power?

Genealogically, Estreich argues that eugenics, capitalism, and problematic metaphors about futures and bodies give rise to the notion of genetic innovation. What kinds of genetic conditions warrant innovation? Are ideas of "perfection," "near perfection," or "imperfection" appropriate descriptors for the DNA, or human life more broadly? Biotechnological innovations such as gene editing and prenatal testing perpetuate harmful associations; language of the "unscripted" and "nebulous" are taken to mean "infected" or "less-than-optimal". Just because difference can be avoided does not mean it should, and Estreich does a fine job questioning the sewn seeds of doubt and fear that innovations and innovators cleverly perpetuate.

\section{References}

Clare, E. (2017). Brilliant imperfection: Grappling with cure. Duke University Press.

Elliott, D. (2019). Neurological disturbances and time travel. Catalyst: Feminism, Theory, Technoscience, 5(2), pp. 1-27.

Ginsburg, F. D. (1989). Contested Lives: The Abortion Debate in An American Community. ([NetLibrary]), ([EBSCO eBook Collection]). University of California Press. http://catdir.loc.gov/catdir/bios/ucalo51/88019887.html 
Rapp, R., \& Ginsburg, F. (2001). Enabling disability: Rewriting kinship, reimagining citizenship. Public Culture, 13(3): 533-56.

Schwartz, M. C. (2007). Growing concerns: Prenatal genetic risks and trust. In Risk and trust: Including or excluding citizens? ed. The Law Commission of Canada, 79101. Black Point, NS: Fernwood Publishers

\section{Author Bio}

Michelle Charette is a PhD student at York University in the Department of Science and Technology Studies. Her research focuses on the oft-reductive explanations of amorphous health conditions, specifically, so-called psychosomatic illnesses (such as fibromyalgia and other forms of chronic pain). One of the central questions guiding her work is, what epistemological underpinnings are operative in our present understanding of "atypical" embodiment? 